\title{
FAKTOR-FAKTOR YANG MEMPENGARUHI NIAT BERINVESTASI GENERASI MILENIAL MELALUI PLATFORM PEER-TO-PEER LENDING
}

\author{
Nandike Ayudiah Poeteri \\ Sekolah Bisnis, IPB University \\ Email: nandike62@apps.sb.ipb.ac.id
}

\begin{abstract}
Peer-to-Peer (P2P) lending merupakan instrumen investasi baru dengan skema pemberian pinjaman secara online. Industri P2P lending berpeluang memberikan sumber alternatif investasi dalam melakukan diversifikasi portofolio, selain dapat membantu peminjam yang tidak dapat mengakses bank konvensional. Pelaku industri P2P lending harus mampu menerapkan strategi untuk meningkatkan kepercayaan konsumen yang berdampak pada meningkatnya niat untuk berinvestasi di platform tersebut sehingga penyaluran dana pinjaman dapat terealisasi dengan baik. Penelitian ini bertujuan menganalisis faktorfaktor yang memengaruhi niat investasi di platform P2P lending melalui kepercayaan sebagai faktor mediasi. Objek dalam penelitian ini adalah generasi milenial di Indonesia dengan jumlah sampel sebanyak 254 responden. Pengambilan sampel dalam penelitian ini menggunakan teknik voluntary sampling dengan kriteria belum pernah melakukan investasi di platform P2P lending, tetapi sudah memiliki jenis investasi lainnya. Data dikumpulkan dengan cara mengisi kuesioner yang disebarkan secara online. Metode analisis statistik yang digunakan adalah Structural Equation Modelling (SEM) dengan menggunakan LISREL. Hasil penelitian menunjukkan bahwa secara langsung persepsi reputasi dan persepsi jaminan struktural memiliki pengaruh signifikan terhadap kepercayaan dan niat investasi. Selain itu, pengaruh tidak langsung antara persepsi reputasi dan persepsi jaminan struktural terhadap niat investasi melalui kepercayaan juga menunjukkan hasil yang signifikan. Dalam penelitian ini menunjukkan bahwa kepercayaan merupakan mediator yang efektif dalam memengaruhi niat invesatsi generasi milenial di platform P2P lending.
\end{abstract}

Kata Kunci: Milenial, niat investasi, P2P lending

\section{PENDAHULUAN}

Generasi milenial merupakan individu yang lahir pada tahun 1982 sampai tahun 2000 (Howe \& Strauss, 2000) atau yang memiliki usia antara 20 sampai 38 tahun di tahun 2020. Generasi tersebut termasuk dalam usia produktif masyarakat Indonesia dan memiliki komposisi jumlah sebanyak 69.38 juta jiwa atau setara dengan $25.87 \%$ dari total penduduk Indonesia (BPS, 2020). Generasi milenial dikenal sebagai generasi yang memiliki karakteristik optimis, percaya diri, fokus pada tujuan, memanfaatkan teknologi, serta fleksibel (Smith \& Nichols, 2015). Tidak jarang generasi tersebut dicirikan sebagai generasi yang memiliki perilaku konsumtif dan cenderung memiliki manajemen keuangan yang buruk (Saputro et al., 2018). Namun, dalam beberapa tahun terakhir ini generasi milenial sudah mulai menyadari pentingnya mengelola keuangan jangka pendek atau jangka panjang dengan menabung atau melakukan investasi. Diungkapkan pada hasil survei Jakpat (2018) bahwa dari dua ribu milenial yang berada di Indonesia, 80\% dari mereka sudah memiliki produk tabungan dan produk investasi yang ditujukan sebagai dana darurat maupun persiapan pensiun. Selain itu, hasil riset DailySocial.id (2020) mengemukakan terdapat beberapa jenis investasi yang saat ini mulai diminati konsumen pada rentang usia 18 sampai dengan 55 tahun dimana diantara usia tersebut merupakan kelompok usia generasi milenial. Adapun jenis investasi yang paling diminati adalah investasi dalam bentuk reksadana (Gambar 1). Namun, beberapa alternatif investasi baru seperti P2P lending dan equity crowdfunding mulai dilirik sebagai produk investasi pilihan berdasarkan teknologi finansial (fintech). 
Gambar 1. Jenis investasi yang diminati usia 18 - 55 tahun

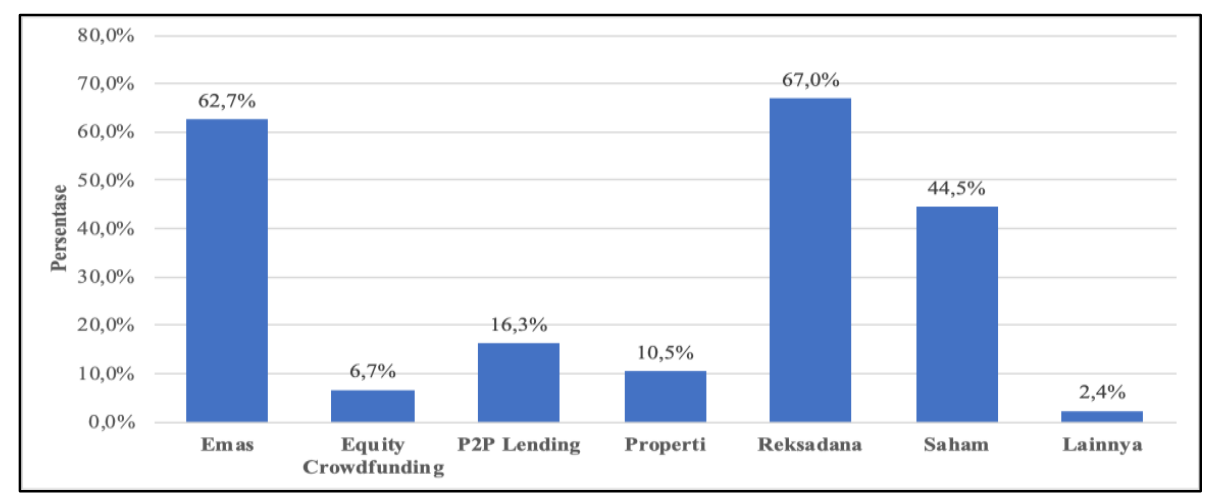

Sumber: DailySocial.id (2020)

Teknologi finansial semakin maju karena dipicu dari berkembangnya teknologi informasi untuk meningkatkan kualitas layanan keuangan dengan memanfaatkan teknologi tersebut. Istilah teknologi finansial menjadi familiar bagi generasi yang bersinggungan dengan perkembangan teknologi informasi dari waktu ke waktu. Menurut Brodmann et al. (2018) generasi pertama yang dapat mengakses teknologi dan memanfaatkan internet adalah generasi milenial. Oleh sebab itu, tingkat adopsi awal teknologi dan pemanfaatan internet telah memberikan peluang bagi layanan keuangan alternatif yang menargetkan konsumen pada generasi tersebut. P2P lending merupakan salah satu teknologi finansial yang sedang berkembang di Indonesia dan memiliki peluang yang sangat luas sebagai bagian dari produk alternatif investasi. Pada dasarnya, P2P lending hadir untuk mengurangi kesenjangan akses peminjaman secara konvensional melalui bank. Mekanisme dalam platform P2P lending didasarkan pada permohonan pinjaman yang memenuhi kriteria kemudian ditempatkan pada platform P2P lending dan dibuka kepada konsumen atau calon investor yang ingin berinvestasi untuk mendapatkan pengembalian sebaik mungkin (Stern et al., 2017).

Penyelenggaraan P2P lending telah diatur pada Peraturan Otoritas Jasa Keuangan (POJK) Nomor 77/POJK.01/2016 tentang layanan pinjam meminjam uang berbasis teknologi informasi. Platform tersebut memberikan kemudahan pelayanan dalam pinjam meminjam berbasis online yang dapat diakses secara real-time. Selain itu, P2P lending mulai diminati karena dapat menjadi alternatif untuk melakukan diversifikasi portofolio investasi dengan skema pemberian pinjaman yang dapat dipilih secara jangka panjang atau jangka pendek. Keberlanjutan industri P2P lending memerlukan keterlibatan investor guna memastikan penyaluran pinjaman yang dibutuhkan peminjam dapat tersalurkan dengan baik. Namun, ditengah semakin diminatinya platform $\mathrm{P} 2 \mathrm{P}$ lending sebagai alternatif investasi masih banyak platform $\mathrm{P} 2 \mathrm{P}$ lending ilegal dan tanpa izin ditemukan oleh Satgas Waspada Investasi (SWI) sejak tahun 2018 (Kominfo.go.id, 2021). Selain itu, penyalahgunaan data pribadi juga semakin marak terjadi pada industri P2P lending (Cnbcindonesia.com, 2019). Sementara, permasalahan tersebut merupakan isu penting pada inovasi-inovasi berbasis teknologi atau online karena pada prinsipnya internet merupakan jaringan terbuka tanpa kontrol manusia secara langsung (Kim et al., 2010). Hal itu dapat menimbulkan kekhawatiran dan berpotensi merugikan konsumen dalam penggunaannya.

Sebagai platform alternatif investasi yang sedang berkembang dikalangan populasi muda, mengukur sikap dalam berinvestasi pada tahap ini dianggap penting mengingat sikap calon investor merupakan bentuk dari niat berperilaku menurut teori tindakan beralasan dimana niat sebagai faktor atas kontrol perbuatan yang direalisasikan dalam perwujudan suatu sikap atau tindakan (Ajzen, 2005). Adanya kepercayaan terhadap platform P2P lending menjadi perhatian dalam menentukan sikap calon investor agar memiliki niat untuk berinvestasi. Dalam konteks digital, beberapa bukti empiris menyatakan bahwa kepercayaan dapat memengaruhi niat untuk menggunakan layanan berbasis teknologi informasi lainnya seperti social commerce (Yahia et al., 2018) dan e-commerce (Fahmi, 2018), dimana kedua layanan tersebut memiliki karakteristik serupa dengan layanan keuangan P2P lending yang dalam transaksinya konsumen tidak bertemu secara langsung dengan penjual ataupun peminjam. Oleh sebab itu, faktor kepercayaan di 
sektor keuangan merupakan unsur fundamental dalam efektivitas perekonomian (Mohy-Ul-Din et al., 2019). Selain itu, keterlibatan persepsi calon investor terhadap reputasi dan jaminan struktural platform $P 2 P$ lending menjadi modal utama lainnya untuk mengatasi permasalahan pada industri tersebut. Reputasi sendiri merupakan nilai tidak berwujud yang membutuhkan komitmen jangka panjang dari sumber daya serta upaya pihak tertentu kepada konsumen (Jang \& Lee, 2018). Konsumen atau calon investor cenderung memiliki kepercayaan jika persepsi reputasi terhadap platform dinilai menguntungkan (Fu et al., 2014). Hal tersebut dibuktikan dari penelitian terdahulu menyatakan bahwa persepsi reputasi dapat memberikan pengaruh yang signifikan terhadap kepercayaan dalam menggunakan layanan berbasis teknologi informasi (Deborah \& Keni, 2019; Herwin \& Abadi, 2018; Shahnaz \& Wahyono, 2016). Selanjutnya, masalah keamanan dalam bertransaksi menjadi hal yang sensitif dalam layanan online. Jaminan struktural berupa kebijakan teknis enkripsi, regulasi, struktur hukum, serta asuransi berfungsi sebagai komponen keamanan ketika melakukan transaksi keuangan di platform P2P lending (Wang et al., 2015). Penelitian McKnight et al. (2002) mengungkapkan bahwa kepercayaan konsumen dalam lingkungan online timbul ketika pihak tertentu memiliki jaminan struktural yang dipersepsikan dapat melindungi aktivitas konsumen. Bukti lainnya pada penelitian terdahulu menunjukkan bahwa persepsi jaminan struktural berpengaruh signifikan terhadap kepercayaan untuk menggunakan layanan teknologi informasi selain P2P lending (Masrek et al., 2018; McCole et al., 2019; Ofori et al., 2017). Nyatanya persepsi reputasi dan persepsi jaminan struktural merupakan anteseden dari faktor kepercayaan terhadap niat untuk berperilaku pada lingkungan online (Kim et al., 2008; McKnight \& Chervany, 2001). Namun, masih terbatasnya penelitian yang menganalisis secara langsung tentang persepsi reputasi dan persepsi jaminan struktural khususnya pada platform P2P lending terhadap niat investasi menjadikan salah satu hal utama untuk mengisi kesenjangan penelitian terdahulu.

Oleh karena itu, penelitian ini bertujuan menganalisis faktor-faktor yang dapat memengaruhi niat berinvestasi generasi milenial di platform P2P lending melalui faktor kepercayaan yang didasarkan pada persepsi reputasi dan persepsi jaminan struktural. Selain itu, penelitian ini akan menganalisis pengaruh langsung dari persepsi reputasi dan persepsi jaminan struktural terhadap niat investasi. Pada akhirnya calon investor dapat menilai sejauh mana investasi yang akan dilakukan dapat menguntungkan dan melindungi atau tidak, sehingga penyelenggara P2P lending diharapkan dapat memahami sikap dan perilaku calon investor untuk berinvestasi di platform tersebut yang memberikan profitabilitas jangka pendek maupun jangka panjang berdasarkan faktor-faktor yang dapat memengaruhinya.

\section{KAJIAN PUSTAKA DAN PENGEMBANGAN HIPOTESIS P2P Lending}

P2P lending merupakan akronim dari Peer-to-Peer lending mengacu pada bentuk transaksi peminjaman antar individu yang terjadi secara langsung melalui platform peminjaman tanpa adanya keterlibatan pihak bank (Yan et al., 2018). Beberapa platform P2P lending bertujuan untuk amal, sementara beberapa platform lainnya memiliki tujuan komersial seperti memfasilitasi proses pinjaman antara peminjam dan pemberi pinjaman (Chen \& Han, 2012). Otoritas Jasa Keuangan (2016) mendefinisikan P2P lending sebagai layanan pinjam meminjam uang dalam mata uang rupiah antara peminjam dengan pemberi pinjaman berbasis teknologi informasi. Mekanisme dalam platform P2P lending didasarkan pada permohonan pinjaman yang memenuhi kriteria kemudian aplikasi pinjaman tersebut ditempatkan pada platform P2P lending dan dibuka kepada calon investor yang ingin berinvestasi untuk mendapatkan pengembalian sebaik mungkin pada tingkat resiko tertentu (Stern et al., 2017). Secara khusus, platform P2P lending dapat berfungsi sebagai cara alternatif investasi dalam bentuk pembiayaan yang nyaman bagi investor individu ketika mendanai pinjaman dalam jumlah kecil dari peminjam.

\section{Niat Investasi}

Niat sebagai faktor atas kontrol perbuatan yang direalisasikan dalam perwujudan suatu sikap atau tindakan (Ajzen, 2005). Niat akan menjadi kecenderungan untuk bertindak hingga mengubah niat tersebut menjadi perilaku. Maruping et al. (2016) mengungkapkan bahwa individu akan membentuk persepsi niat berperilaku dalam upaya untuk melakukan suatu tindakan berdasarkan aspek internal. Dalam hal penggunaan teknologi, beberapa faktor eksternal akan memengaruhi sikap yang didasarkan atas pendapat 
individu bahwa penggunaan teknologi tersebut akan mendatangkan hasil tertentu (Van Deventer et al., 2017). Lebih lanjut, melakukan investasi merupakan salah satu bentuk perbuatan yang terwujud pada suatu sikap untuk berinvestasi. Sikap dari pelaku investasi dalam niat berinvestasi ditunjukkan dari beberapa faktor pendukung diantaranya terdapat motivasi, tujuan yang jelas, mengetahui yang akan dilakukan, serta manajemen waktu (Septyanto, 2013). Lebih khusus, penelitian ini akan mengkaji niat investasi dalam penggunaan platform $\mathrm{P} 2 \mathrm{P}$ lending sebagai salah satu media alternatif investasi.

\section{Kepercayaan}

Kepercayaan diyakini sebagai persepsi individu bahwa suatu objek memiliki karakteristik yang dapat dipercaya memberikan manfaat (McKnight et al., 2002). Sejalan dengan hal tersebut Koksal (2016) mengungkapkan bahwa kepercayaan diartikan sebagai kemungkinan subjektif yang diyakini bahwa kondisi tertentu terjadi secara konsisten sesuai dengan ekspektasi. Konsep kepercayaan pada dasarnya menyangkut keyakinan konsumen terhadap suatu pihak tertentu terkait ability, integrity, dan benevolence (Gunarso et al., 2020). Dalam hal ini, kepercayaan konsumen yaitu investor terhadap platform P2P lending menjadi hal yang penting karena investor hanya dapat mengakses informasi investasi atau pemberian pinjaman melalui informasi yang diberikan pada platform. McKnight \& Chervany (2001) mengungkapkan bahwa salah satu acuan yang dapat memengaruhi kepercayaan konsumen dalam lingkungan online adalah institutionalbased, dimana jaminan struktural yang diberikan pihak tertentu menjadi faktor penting untuk mendukung kesuksesan bertransaksi. Selain itu, Kim et al. (2008) menambahkan terdapat empat acuan lainnya yang memengaruhi kepercayaan konsumen diantaranya cognition-based, affect-based, experience-based, dan personality-oriented. Penelitian ini akan mengkaji kepercayaan investor yang mengacu institutional-based berdasarkan jaminan struktural dalam platform dan affect-based yang berhubungan pada interaksi tidak langsung dengan pihak tertentu berdasarkan reputasi dari platform P2P lending.

\section{Persepsi Reputasi}

Persepsi reputasi diartikan sebagai sejauh mana individu meyakini bahwa pihak tertentu memiliki kejujuran dan kepedulian terhadap konsumennya (Bojang, 2017). Reputasi sendiri merupakan nilai tidak berwujud dan membutuhkan komitmen jangka panjang dari sumber daya serta upaya pihak tertentu kepada konsumen (Jang \& Lee, 2018). Lebih lanjut, reputasi juga dianggap sebagai tingkat popularitas yang dilihat oleh konsumen (Hsiao et al., 2010). Reputasi yang dirasakan oleh konsumen pada pihak tertentu menjadi bentuk anteseden akibat dari interaksi jangka panjang. Dalam hal ini platform P2P lending merupakan pihak tertentu yang memiliki kemampuan untuk menjadi media alternatif selain bank bagi peminjam dan pemberi pinjaman/investor. Semakin banyaknya platform P2P lending yang terdaftar pada Otoritas Jasa Keuangan dapat memberikan alternatif pilihan tempat berinvestasi, namun masing-masing platform memiliki reputasi dan kredibilitas yang berbeda sebagai platform P2P lending. Jika konsumen merasakan bahwa reputasi pihak tertentu lebih menguntungkan, maka konsumen akan cenderung memiliki sikap yakin (Fu et al., 2014). Selain itu, Wang et al. (2014) menjelaskan bahwa reputasi menjadi salah satu dasar bagi konsumen yang belum memiliki pengalaman berinvestasi di P2P lending untuk bergantung dan percaya terhadap platform tersebut. Hal ini didasarkan bahwa platform P2P lending yang masih baru dikenal di masyarakat Indonesia memiliki sumber informasi yang terbatas, selain dari platform tersebut yang memberikan informasi tentang investasi berbasis pemberian pinjaman kepada konsumen.

\section{Persepsi Jaminan Struktural}

Persepsi jaminan struktural mengacu tingkat keyakinan konsumen pada fitur-fitur keamanan seperti perlindungan hukum, kontrak, jaminan, atau kebijakan teknis untuk meminimalkan kecemasan dalam bertransaksi menggunakan teknologi (Wang et al., 2014; Wingreen et al., 2019). Sebagai media investasi baru, platform P2P lending menggunakan teknologi informasi dalam seluruh aktivitasnya untuk mempertemukan peminjam dengan pemberi pinjaman/investor secara online. Elemen-elemen digital pada platform tersebut berpotensi memicu kekhawatiran dalam penggunaannya. Masalah keamanan dalam bertransaksi menjadi hal yang sensitif dalam layanan online bagi konsumen yang menginginkan terjaminnya privasi. Wang et al. (2015) mengungkapkan bahwa jaminan struktural berupa kebijakan teknis enkripsi, regulasi, struktur hukum, serta asuransi berfungsi sebagai komponen keamanan ketika melakukan 
transaksi keuangan di platform P2P lending. Tingkat jaminan struktural yang dinilai semakin baik dapat membantu konsumen untuk mengatasi potensi kerugian dan terlindungi dari hilangnya informasi identitas/privasi serta keuangan (Wang et al., 2019). Lebih lanjut, McKnight et al. (2002) mengungkapkan bahwa kepercayaan konsumen dalam lingkungan online timbul ketika pihak tertentu memiliki jaminan struktural yang dapat melindungi aktivitas konsumen. Kehadiran jaminan struktural memberikan keyakinan konsumen untuk dapat terlindungi dan memastikan aktivitas bisnis online dilakukan dengan cara yang aman dan terjamin (Kim, 2012). Oleh karena itu, keberadaan jaminan struktural menjadi penting dalam mempromosikan keberhasilan transaksi yang dilakukan secara online.

\section{Pengaruh Persepsi Reputasi Terhadap Kepercayaan dan Niat Investasi}

Penelitian Shahnaz \& Wahyono (2016) menunjukkan bahwa pengaruh reputasi memberikan efek positif dan signifikan terhadap kepercayaan konsumen. Adanya persepsi bahwa semakin positif reputasi pihak tertentu yang dirasakan akan menunjukkan tingkatan kepercayaan konsumen. Hal tersebut didukung pada penelitian Deborah \& Keni (2019) bahwa reputasi website yang semakin dinilai positif memberikan pengaruh yang kuat terhadap kepercayaan pengguna. Penelitian Herwin \& Abadi (2018) juga menunjukkan bahwa reputasi perusahaan yang positif akan memengaruhi kepercayaan konsumen untuk bertransaksi khususnya di e-commerce. Dalam konteks P2P lending adanya pengaruh reputasi menunjukkan efek yang sama seperti penggunaan e-commerce untuk bertransaksi (Yang et al., 2017). Hal ini menunjukkan bahwa dari segi persepsi konsumen, semakin tinggi nilai reputasi pihak tertentu dalam bisnis berbasis online akan meningkatkan kepercayaan konsumen untuk menggunakan teknologi tersebut dibandingkan yang tidak dikenal. Selain itu, terdapat potensi bahwa persepsi konsumen terhadap reputasi pihak tertentu yang tinggi maka penggunaan teknologi tersebut dimungkinkan (Tangmanee \& Rawsena, 2016). Penelitian Shao et al. (2018) menemukan bahwa reputasi secara langsung dapat menunjukkan pengaruh signifikan terhadap niat menggunakan platform mobile payment dan dimediasi oleh kepercayaan. Hal ini didukung oleh tanggapan bahwa reputasi perusahaan atau pihak tertentu yang dirasakan dapat memengaruhi niat konsumen untuk berperilaku (Kircova \& Esen, 2018). Berdasarkan hasil pemaparan penelitian terdahulu, maka hipotesis yang diajukan adalah:

H1: Persepsi reputasi berpengaruh signifikan terhadap kepercayaan di platform P2P lending H2: Persepsi reputasi berpengaruh signifikan terhadap niat investasi di platform P2P lending

\section{Pengaruh Persepsi Jaminan Struktural Terhadap Kepercayaan dan Niat Investasi}

Ofori et al. (2017) mengungkapkan bahwa ketersediaan jaminan struktural dapat memengaruhi kepercayaan konsumen khususnya dalam penggunaan layanan keuangan berupa internet banking. Dalam penelitiannya, jaminan struktural berupa kompensasi dan perlindungan data pribadi menjadi sangat penting pada layanan keuangan berbasis online. Didukung pada penelitian Masrek et al. (2018) yang menunjukkan bahwa unsur keamanan dan perlindungan privasi yang dimiliki layanan keuangan semakin kredibel maka tingkat kepercayaan konsumen akan meningkat. Lebih lanjut, dalam konteks e-service lainnya jaminan struktural memengaruhi secara signifikan terhadap kepercayaan konsumen (McCole et al., 2019). Hal ini menunjukkan bahwa keberadaan jaminan struktural pada layanan berbasis online dipersepsikan sangat penting oleh konsumen untuk menjamin keamanan keuangan maupun data pribadi. Khususnya pada penggunaan platform $\mathrm{P} 2 \mathrm{P}$ lending untuk berinvestasi, isu-isu mengenai penyalahgunaan data pribadi masih memicu kekhawatiran konsumen. Disamping itu, jaminan perlindungan dalam bertransaksi di platform atau website keuangan lainnya yang dapat diandalkan dan kredibel memicu niat konsumen untuk menggunakan platform tersebut (Rahi et al., 2017). Hal yang sama juga diungkapkan pada penelitian Maduku (2016) yang menyatakan bahwa jaminan struktural memainkan peran kunci dalam menentukan sikap konsumen terhadap penggunaan layanan keuangan seperti internet banking serta memengaruhi niat penggunaan layanan tersebut di masa mendatang. Berdasarkan hasil pemaparan penelitian terdahulu, maka hipotesis yang diajukan adalah:

\section{H3: Persepsi jaminan struktural berpengaruh signifikan terhadap kepercayaan di platform P2P lending}

H4: Persepsi jaminan struktural berpengaruh signifikan terhadap niat investasi di platform P2P Lending 


\section{Pengaruh Kepercayaan Terhadap Niat Investasi}

Penelitian Yahia et al. (2018) menemukan bahwa kepercayaan menjadi faktor penting dalam memengaruhi niat penggunaan platform social commerce oleh konsumen. Selain itu, dalam penelitiannya juga menyatakan bahwa kepercayaan dapat memediasi pengaruh reputasi platform terhadap niat untuk menggunakan. Hal yang sama diungkapkan pada hasil penelitian Akroush \& Al-Debei (2015) menemukan bahwa kepercayaan juga dapat menjadi mediasi antara pengaruh reputasi terhadap sikap berbelanja online. Pada penelitian e-commerce, kepercayaan memiliki pengaruh yang kuat terhadap niat konsumen untuk menggunakan layanan tersebut (Fahmi, 2018). Dalam lingkungan online, kepercayaan terhadap berbagai macam platform berbasis teknologi informasi memiliki peran utama dalam memengaruhi sikap konsumen. Lebih lanjut, dalam konteks layanan keuangan, kepercayaan konsumen telah memengaruhi niat untuk menggunakan layanan keuangan tersebut secara positif dan signifikan, namun kepercayaan juga dinilai sebagai faktor yang dapat menjadi mediasi antara reputasi pihak tertentu dan jaminan struktural terhadap niat penggunaan layanan keuangan (Ahmed \& Ali, 2017). Dalam konteks investasi, kepercayaan memiliki pengaruh yang positif dan signifikan terhadap niat untuk berinvestasi di online trading platforms (Maziriri et al., 2019). Berdasarkan hasil pemaparan penelitian terdahulu, maka hipotesis yang diajukan adalah:

\section{H5: Kepercayaan berpengaruh signifikan terhadap niat investasi di platform P2P lending}

\section{Gambar 3. Kerangka Konseptual}

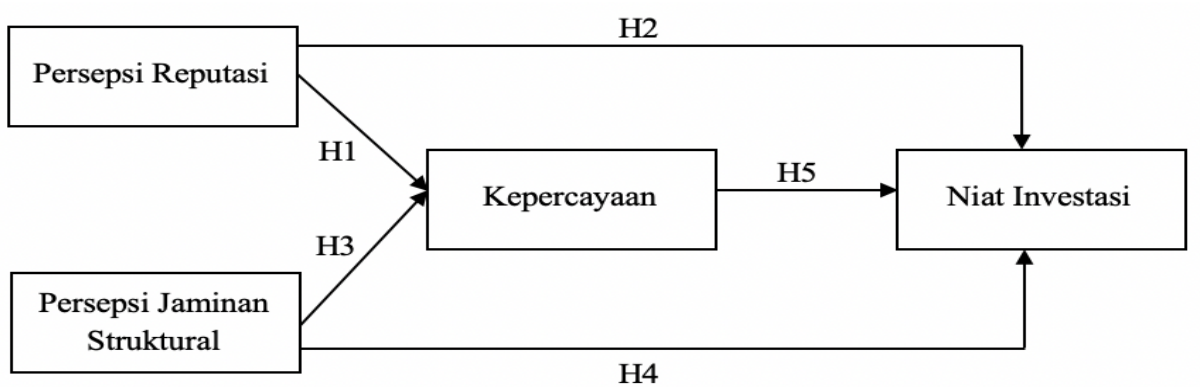

\section{METODE PENELITIAN}

Penelitian ini menggunakan pendekatan kuantitatif dengan metode survei yang dilakukan hanya pada waktu tertentu. Pengambilan sampel dalam penelitian ini dilakukan dengan teknik voluntary sampling yang didasarkan atas kesukarelaan sampel untuk berpartisipasi dalam penelitian namun dibatasi dalam kondisi tertentu. Batasan tersebut diantaranya responden yang lahir antara tahun 1982 hingga 2000 serta belum pernah melakukan investasi di platform P2P lending namun memiliki kepemilikan jenis investasi lainnya. Menurut Hair et al. (2006) dibutuhkan jumlah sampel pada setiap estimasi parameter variabel endogen dan eksogen sebanyak lima hingga sepuluh observasi. Jumlah indikator yang tersusun dipenelitian ini ada sebanyak 16 indikator, oleh karena itu jumlah responden yang dibutuhkan berada dalam rentang 166 - 320 responden. Penelitian ini mendapatkan 254 responden yang sesuai kriteria dan mengisi kuesioner online secara lengkap melalui Google Docs. Data primer didapatkan dari kuesioner, sementara data sekunder didapatkan dari berbagai macam literatur yang mendukung hipotesis dalam penelitian ini.

Kuesioner yang diajukan terbagi atas tiga bagian, yaitu screening, profiling, dan pertanyaan mengenai variabel penelitian. Kuesioner disebarkan melalui jejaring sosial Skala yang digunakan dalam instrumen adalah skala Likert lima tingkat, yaitu (1) sangat tidak setuju, (2) tidak setuju, (3) cukup setuju, (4) setuju, dan (5) sangat setuju. Variabel dependen pada penelitian ini adalah niat investasi (NI), sementara variabel independen pada penelitian ini meliputi persepsi reputasi (PR) dan persepsi jaminan struktural (JS) serta variabel antara yaitu kepercayaan (KP). Analisis hubungan antar variabel dalam penelitian ini menggunakan Structural Equation Modelling (SEM) dengan bantuan software LISREL. Menurut Sugiharto dan Sitinjak (2004) SEM mampu menganalisis variabel laten, variabel indikator, serta menghitung kesalahan pengukuran dalam model berdasarkan evaluasi tingkat kecocokan model. Evaluasi tingkat kecocokan model pada SEM terdiri atas uji kecocokan keseluruhan model, uji kecocokan model pengukuran, dan uji kecocokan model struktural. 


\section{HASIL PENELITIAN \\ Karakteristik Responden}

Responden dalam penelitian adalah generasi milenial dengan jenis kelamin wanita (130 orang) dan laki-laki (124 orang). Usia milenial dalam penelitian ini terbagi dalam tiga kelompok usia diantaranya usia 20-25 tahun (50 orang), 26-31 tahun (172 orang), dan 32-38 tahun (32 orang). Milenial dengan latar belakang pendidikan sarjana (S1) mendominasi dalam penelitian ini yaitu $77.2 \%$, sisanya berpendidikan SMA, diploma, dan pascasarjana. Sementara pada kategori pekerjaan milenial dari yang mendominasi adalah pegawai swasta (54.7\%), mahasiswa (13.0\%), ASN/TNI/POLRI (10.2\%), wiraswasta (9.4\%), pegawai BUMN (9.2\%), dan ibu rumah tangga (3.5\%). Rata-rata penghasilan per bulan responden milenial kurang dari Rp 5.000.000 sebesar 29.9\%, antara Rp 5.000.000 hingga Rp 10.000.000 sebesar 44.9\%, dan lebih dari $\mathrm{Rp} 10.000 .000$ sebesar $25.2 \%$. Domisili milenial dalam penelitian didominasi pada milenial yang tinggal di wilayah Pulau Jawa (91.6\%) dan sisanya berasal dari luar wilayah Pulau Jawa (8.4\%). Sebesar 94.6\% responden milenial sudah memiliki investasi seperti emas $(31.0 \%)$, properti $(14.1 \%)$, deposito (19.2\%), saham (11.9\%), reksadana (12.1\%), dan obligasi (6.3\%), sementara 5.4\% memiliki investasi jenis lainnya seperti foreign exchange trading, tanah, peternakan, dan mendanai kegiatan bisnis secara langsung.

\section{Uji Kecocokan Keseluruhan Model}

Uji kecocokan keseluruhan model pada penelitian ini ditinjau dari beberapa kriteria Goodness-ofFit. Secara keseluruhan, model dapat diterima karena telah memenuhi kriteria yang sudah ditentukan (Hair et al., 2006). Dengan demikian, model tersebut dapat digunakan untuk mengevaluasi variabel persepsi reputasi, persepsi jaminan struktural, kepercayaan, dan niat investasi. Tabel 1 menunjukkan hasil uji kecocokan keseluruhan model (Goodness-of-Fit).

Tabel 1. Nilai Goodness-of-Fit

\begin{tabular}{lccc}
\hline Kriteria Goodness-of-Fit & Cut-off & Hasil & Keterangan \\
\hline Root Mean Error Approximation (RMSEA) & $\leq 0.08$ & 0.15 & Marginal fit \\
Good Fit Index (GFI) & $\geq 0.9$ & 0.75 & Marginal fit \\
Adjusted Good Fit Index (AGFI) & $\geq 0.9$ & 0.65 & Marginal fit \\
Normed Fit Index (NFI) & $\geq 0.9$ & 0.91 & Good fit \\
Comparative Fit Index (CFI) & $\geq 0.9$ & 0.93 & Good fit \\
Incremental Fit Index (IFI) & $\geq 0.9$ & 0.93 & Good fit \\
Relative Fit Index (RFI) & $\geq 0.9$ & 0.90 & Good fit \\
\hline
\end{tabular}

Uji Kecocokan Model Pengukuran

Kriteria kecocokan model pengukuran ditinjau berdasarkan validitas dan reliabilitas variabel indikator terhadap variabel latennya. Suatu indikator dinyatakan valid apabila memiliki nilai loading factor yang dapat ditoleransi yaitu $\geq 0.5$ dan t-hitung di atas 1.96 dengan tingkat kepercayaan $95 \%$ (Hair et al., 2006). Tabel 2 menunjukkan bahwa seluruh indikator pengukuran telah merefleksikan konstruk laten pada model, sehingga indikator untuk setiap konstruk laten dinyatakan valid.

Tabel 2. Hasil uji kecocokan model pengukuran PR, JS, KP, dan NI

\begin{tabular}{lcccc}
\hline Variabel Laten & Indikator & Loading Factor & $\mid$ t-hitung| & Keterangan \\
\hline Persepsi Reputasi (PR) & PR1 & 0.61 & 10.19 & Valid \\
& PR2 & 0.83 & 15.58 & Valid \\
& PR3 & 0.82 & 15.30 & Valid \\
& PR4 & 0.67 & 11.47 & Valid \\
Persepsi Jaminan Struktural (JS) & PR5 & 0.61 & 10.22 & Valid \\
& JS1 & 0.83 & 15.54 & Valid \\
& JS2 & 0.81 & 15.07 & Valid \\
Kepercayaan (KP) & JS3 & 0.79 & 14.50 & Valid \\
& JS4 & 0.81 & 14.93 & Valid \\
& KP1 & 0.68 & - & Valid \\
& KP2 & 0.72 & 10.48 & Valid \\
\hline
\end{tabular}




\begin{tabular}{lcccc}
\hline & KP3 & 0.84 & 11.92 & Valid \\
Niat Investasi (NI) & KP4 & 0.89 & 12.59 & Valid \\
& NI1 & 0.96 & - & Valid \\
& NI2 & 0.93 & 30.84 & Valid \\
& NI3 & 0.86 & 23.09 & Valid \\
\hline
\end{tabular}

Berbeda dari uji validitas, penilaian reliabilitas ditinjau berdasarkan Variance Extracted (VE) dan Construct Reliability (CR). Hasil penelitian diperoleh bahwa persepsi reputasi, persepsi jaminan struktural, kepercayaan, dan niat investasi memenuhi syarat dengan nilai $C R \geq 0.7$ dan VE $\geq 0.5$ (Hair et al., 2006). Hasil tersebut mengindikasikan bahwa setiap variabel indikator dapat diandalkan untuk mengukur konstruk latennya (Tabel 3).

Tabel 3. Hasil construct reliability (CR) dan variance extracted (VE)

\begin{tabular}{lccc}
\hline Variabel laten & Indikator & VE & CR \\
\hline Persepsi Reputasi & PR1 - PR5 & 0.51 & 0.84 \\
Persepsi Jaminan Struktural & JS1 - JS4 & 0.66 & 0.88 \\
Kepercayaan & KP1 - KP4 & 0.62 & 1.73 \\
Niat Investasi & NI1 - NI3 & 0.84 & 0.94 \\
\hline
\end{tabular}

\section{Uji Kecocokan Model Struktural}

Uji kecocokan model struktural dilakukan terhadap koefisien-koefisien persamaan struktural dengan melakukan spesifikasi tingkat signifikasi tertentu. Diagram jalur pada model struktural tersaji pada Gambar 4. Hasil tersebut menunjukkan bahwa seluruh variabel manifest (indikator) memiliki nilai standardized loading factor lebih dari 0.5 sesuai dengan batas toleransi yang dapat diterima. Selanjutnya, nilai koefisien jalur pada setiap hipotesis yaitu H1 (PR $\rightarrow$ KP: 0.53), H2 (PR $\rightarrow$ NI: -0.19 ), H3 (JS $\rightarrow$ KP: 0.32), H4 (JS $\rightarrow$ NI: 0.16), dan H5 (KP $\rightarrow$ NI: 0.89).

\section{Gambar 4. Diagram jalur model struktural}

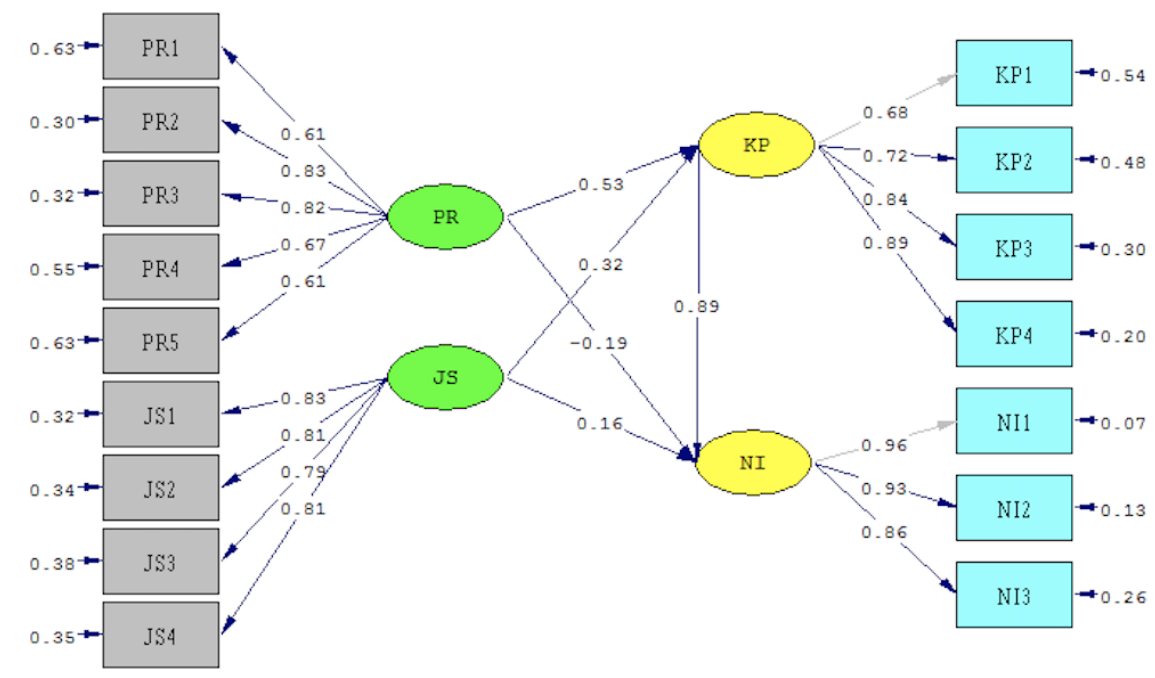

Analisis pada model struktural juga termasuk hasil signifikan setiap pengaruh konstruk yang diestimasi. Diagram t-hitung pada model struktural tersaji pada Gambar 5. Nilai t-hitung pada setiap konstruk seluruh hipotesis menunjukkan nilai di atas 1.96, yaitu H1 (PR $\rightarrow \mathrm{KP}: 6.23), \mathrm{H} 2(\mathrm{PR} \rightarrow \mathrm{NI}: 2.35)$, $\mathrm{H} 3$ (JS $\rightarrow$ KP: 4.02), H4 (JS $\rightarrow$ NI: 2.44), dan H5 (KP $\rightarrow$ NI: 8.86). 


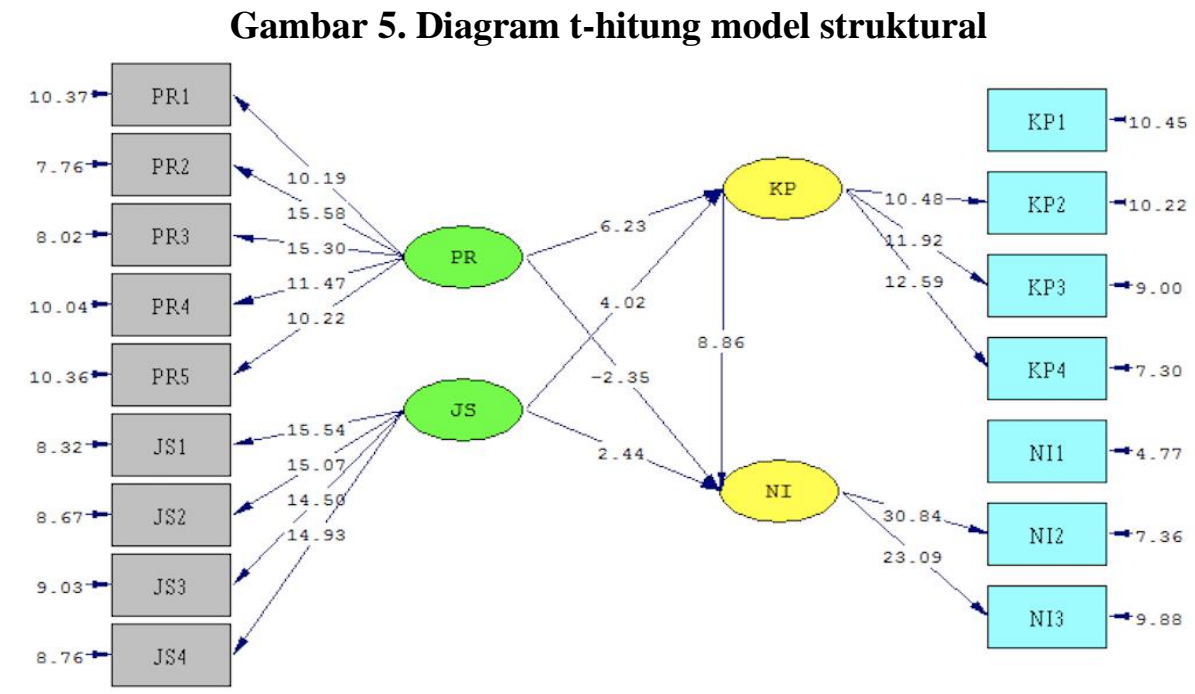

\section{PEMBAHASAN}

Berdasarkan pengujian hipotesis diketahui bahwa seluruh hipotesis yang diajukan yaitu $\mathrm{H} 1, \mathrm{H} 2$, $\mathrm{H} 3$, H4, dan $\mathrm{H} 5$ memiliki nilai t-hitung > 1.96 yang menandakan terdapat pengaruh signifikan dan hipotesis diterima. Hasil estimasi model SEM berdasarkan pengaruh langsung tersaji pada Tabel 4. Hasil pengujian hipotesis pertama $(\mathrm{H} 1)$ menunjukkan bahwa variabel persepsi reputasi memiliki pengaruh yang positif dan signifikan terhadap kepercayaan responden pada platform P2P lending dengan nilai koefisien jalur 0.53 dan t-hitung 6.23. Hal ini menunjukkan bahwa semakin tinggi tingkat persepsi reputasi generasi milenial terhadap platform P2P lending dapat meningkatkan kepercayaan pada platform tersebut. Hasil ini sejalan dengan penelitian terdahulu yang menyatakan bahwa reputasi pihak tertentu yang dirasakan oleh konsumen semakin dinilai positif maka secara signifikan memengaruhi kepercayaan konsumen dalam menggunakan layanan tersebut (Deborah \& Keni, 2019; Herwin \& Abadi, 2018; Shahnaz \& Wahyono, 2016; Yang et al., 2017). Indikator persepsi reputasi yang memiliki kontribusi paling kuat adalah platform P2P lending dikenal sebagai media alternatif berinvestasi serta sebagai pemodalan alternatif oleh responden, selain itu popularitas platform P2P lending juga dapat memengaruhi pandangan responden untuk menggunakan platform tersebut dalam berinvestasi. Hal tersebut didukung oleh Hsiao et al. (2010) yang mengungkapkan bahwa tingkat popularitas dianggap sebagai penentu reputasi dari pihak tertentu yang dirasakan oleh konsumen.

Tabel 4. Uji hipotesis pengaruh langsung antar variabel

\begin{tabular}{lclccc}
\hline \multicolumn{2}{c}{ Pengaruh Variabel } & & $\begin{array}{c}\text { Koef. } \\
\text { Jalur }\end{array}$ & $\mid$ t-hitung $\mid$ & Keterangan \\
\hline Persepsi Reputasi & $\rightarrow$ & Kepercayaan & 0.53 & 6.23 & Terima H1 \\
Persepsi Reputasi & $\rightarrow$ & Niat Investasi & -0.19 & 4.02 & Terima H2 \\
Persepsi Jaminan Sruktural & $\rightarrow$ & Kepercayaan & 0.32 & 2.35 & Terima H3 \\
Persepsi Jaminan Struktural & $\rightarrow$ & Niat Investasi & 0.16 & 2.44 & Terima H4 \\
Kepercayaan & $\rightarrow$ & Niat Investasi & 0.89 & 8.86 & Terima H5 \\
\hline
\end{tabular}

Berikutnya, hasil pengujian hipotesis kedua $(\mathrm{H} 2)$ menunjukkan bahwa variabel persepsi reputasi memiliki pengaruh langsung secara signifikan terhadap niat investasi di platform P2P lending. Hal tersebut ditunjukkan pada nilai t-hitung sebesar 4.02 yang menandakan bahwa hipotesis tersebut diterima. Hasil tersebut didukung oleh penelitian Kircova \& Esen (2018) yang mengungkapkan bahwa reputasi perusahaan atau pihak tertentu yang dirasakan dapat memengaruhi niat konsumen untuk berperilaku. Nilai koefisien jalur yang dihasilkan pada pengaruh antar variabel tersebut adalah -0.19. Berdasarkan hasil pengujian dapat disimpulkan bahwa persepsi reputasi secara langsung dapat memengaruhi niat responden, namun tidak 
demikian dapat meningkatkan niat responden untuk berinvestasi di platform P2P lending. Kondisi tersebut diduga bahwa platform $\mathrm{P} 2 \mathrm{P}$ lending cenderung sebagai media alternatif investasi yang baru dikenal oleh responden dibandingkan dengan kepemilikan dari jenis-jenis investasi lainnya. Selain itu, responden merasa platform P2P lending belum sepenuhnya memiliki reputasi yang baik. Sejalan dengan hal itu, Tangmanee \& Rawsena (2016) mengatakan bahwa reputasi pihak tertentu yang semakin tinggi maka penggunaan teknologi tersebut dimungkinkan, namun sebaliknya apabila reputasi yang dirasakan cenderung rendah maka menimbulkan keengganan untuk menggunakannya.

Selanjutnya, hasil pengujian hipotesis ketiga (H3) menunjukkan bahwa variabel persepsi jaminan struktural memiliki pengaruh yang positif dan signifikan terhadap kepercayaan responden di platform $\mathrm{P} 2 \mathrm{P}$ lending dengan nilai koefisien jalur sebesar 0.32 dan t-hitung sebesar 2.35. Hal ini dapat diartikan bahwa semakin tinggi persepsi konsumen terhadap jaminan struktural pada platform maka diduga dapat meningkatkan kepercayaan konsumen jika menggunakan platform P2P lending sebagai instrumen investasi. Hasil penelitian ini sejalan dengan penelitian terdahulu yang mengungkapkan bahwa ketersediaan jaminan struktural secara signifikan memengaruhi kepercayaan konsumen dalam menggunakan berbagai macam layanan berbasis online (Masrek et al., 2018; McCole et al., 2019; Ofori et al., 2017). Sementara itu, indikator persepsi jaminan struktural yang memiliki kontribusi paling kuat adalah responden merasa yakin bahwa berinvestasi di platform P2P lending terdapat perlindungan hukum, teknologi keamanan, jaminan asuransi untuk memastikan keberhasilan transaksi serta melindungi dana investasi. Namun, keyakinan responden bahwa terdapat perlindungan privasi untuk memberikan rasa aman dalam bertransaksi masih cenderung rendah. Hal ini diduga bahwa masih terdapatnya isu-isu mengenai penyalahgunaan data pribadi yang memicu kekhawatiran responden.

Hasil pengujian hipotesis keempat (H4) menunjukkan bahwa variabel persepsi jaminan struktural secara langsung dapat memengaruhi niat responden untuk berinvestasi di platform P2P lending. Hal ini ditunjukkan dari nilai t-hitung sebesar 2.44 yang menandakan bahwa hipotesis keempat diterima. Selain itu, nilai koefisien jalur pada pengaruh antar variabel ini menunjukkan nilai yang positif yaitu sebesar 0.16. Artinya bahwa semakin tinggi persepsi responden terhadap jaminan struktural cenderung akan meningkatkan niat untuk berinvestasi di platform P2P lending. Hasil ini didukung oleh penelitian Maduku (2016) yang menemukan bahwa jaminan struktural memiliki peran kunci dalam menentukan sikap konsumen terhadap penggunaan layanan keuangan. Selain itu dalam penelitiannya ketersediaan jaminan struktural juga memengaruhi niat penggunaan layanan tersebut oleh konsumen. Dalam hal ini Rahi et al., (2017) mengungkapkan bahwa adanya jaminan perlindungan dalam melakukan transaksi menggunakan teknologi keuangan yang dapat diandalkan dan kredibel cenderung akan membangkitkan niat konsumen untuk memanfaatkan layanan tersebut.

Selanjutnya, hasil pengujian hipotesis kelima (H5) menunjukkan bahwa variabel kepercayaan dapat memengaruhi niat responden untuk berinvestasi di platform P2P lending secara positif dan signifikan. Hal ini ditunjukkan pada nilai t-hitung sebesar 8.86 yang berarti bahwa hipotesis kelima diterima. Selain itu, nilai koefisien jalur menunjukkan arah yang positif yaitu sebesar 0.89 . Berdasarkan hasil penelitian dapat disimpulkan bahwa semakin tinggi kepercayaan responden terhadap platform P2P lending maka cenderung akan meningkatkan niat untuk berinvestasi di platform tersebut. Hasil penelitian ini sejalan dengan penelitian terdahulu yang menemukan bahwa faktor kepercayaan dapat memengaruhi niat untuk menggunakan platform online (Maziriri et al., 2019; Yahia et al., 2018; Fahmi, 2018). Indikator kepercayaan yang memiliki kontribusi paling kuat adalah responden merasa bahwa platform P2P lending dapat diandalkan sebagai media alternatif investasi yang mampu memberikan peluang investasi dalam memenuhi komitmennya untuk kesejahteraan keuangan investor. Dalam hal ini responden memiliki kepercayaan dan ketertarikan untuk berinvestasi di platform P2P lending serta berniat untuk melakukan investasi di masa yang akan datang dengan mencari lebih banyak informasi mengenai investasi di platform $\mathrm{P} 2 \mathrm{P}$ lending.

Selain pengaruh langsung antar variabel penelitian, hasil perhitungan juga menunjukkan adanya pengaruh tidak langsung dari persepsi reputasi dan persepsi jaminan struktural melalui kepercayaan dalam memengaruhi niat investasi responden pada platform P2P lending. Pengaruh yang signifikan ditunjukkan dari nilai t-hitung > 1.96 (Tabel 5). 
Tabel 5. Pengaruh tidak langsung antar variabel

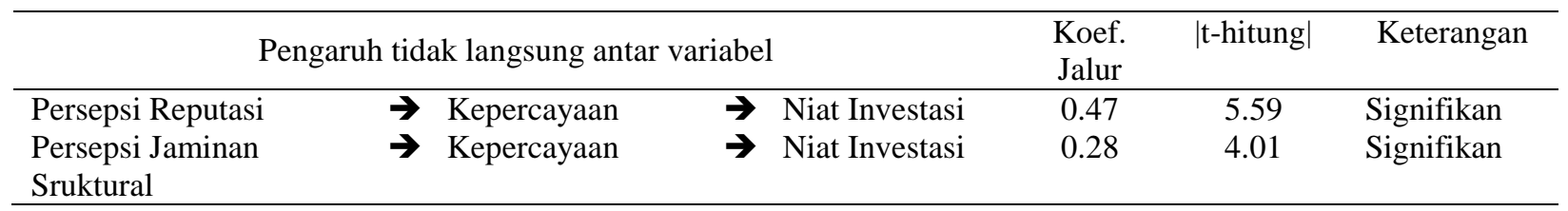

Pengaruh tidak langsung dari persepsi reputasi terhadap niat investasi melalui kepercayaan menunjukkan hasil yang signifikan. Hal ini ditunjukkan dengan nilai t-hitung sebesar 5.59 yaitu lebih dari nilai signifikansi di atas 1.96 . Temuan ini dapat disimpulkan bahwa jika penyelenggara P2P lending meningkatkan persepsi reputasi konsumen terhadap platform tersebut maka akan meningkatkan kepercayaan konsumen yang kemudian berdampak pada niat konsumen untuk berinvestasi di platform P2P lending. Hasil tersebut didukung oleh penelitian terdahulu yang dilakukan oleh Akroush \& Al-Debei (2015) bahwa kepercayaan menjadi faktor mediasi yang dapat memengaruhi persepsi reputasi terhadap sikap untuk berperilaku dari konsumen. Selanjutnya, pengaruh tidak langsung dari persepsi jaminan struktural terhadap niat investasi melalui kepercayaan menunjukkan nilai t-hitung sebesar 4.01. Berdasarkan hasil temuan bahwa pengaruh tidak langsung tersebut dapat disimpulkan memiliki pengaruh yang signifikan karena nilai t-hitung menunjukkan nilai di atas 1.96. Hal ini dapat diartikan bahwa jika penyelenggara P2P lending meningkatkan persepsi jaminan struktural yang dirasakan oleh konsumen maka akan meningkatkan kepercayaan konsumen yang berdampak pada niat konsumen untuk berinvestasi di platform P2P lending. Temuan tersebut sejalan dengan penelitian yang dilakukan oleh Ahmed \& ali (2017) bahwa kepercayaan dinilai sebagai faktor yang efektif untuk memediasi antara jaminan struktural terhadap niat penggunaan layanan keuangan selain dari reputasi pihak tertentu.

Berikutnya, besar pengaruh tidak langsung dari persepsi reputasi terhadap niat investasi di platform P2P lending melalui kepercayaan adalah 0.47 , sedangkan pengaruh reputasi terhadap niat investasi di platform P2P lending secara langsung adalah -0.19. Sementara besar pengaruh tidak langsung dari persepsi jaminan struktural terhadap niat investasi di platform P2P lending melalui kepercayaan adalah 0.28, sedangkan pengaruh jaminan struktural terhadap niat investasi di platform P2P lending secara langsung adalah 0.16. Meskipun masing-masing pengaruh baik secara langsung maupun tidak langsung memiliki pengaruh yang signifikan, tetapi pengaruh tidak langsung persepsi reputasi dan persepsi jaminan struktural memiliki nilai koefisien jalur yang lebih besar sehingga pengaruhnya pun lebih kuat jika dibandingkan dengan pengaruh langsungnya. Hal ini dapat disimpulkan bahwa dengan meningkatkan kepercayaan secara efektif dapat memediasi persepsi reputasi dan persepsi jaminan struktural terhadap niat investasi di platform P2P lending. Hasil temuan ini didukung oleh penelitian terdahulu yang dilakukan Kaabachi et al. (2017) bahwa faktor kepercayaan secara simultan dapat menjadi mediator yang efektif untuk memengaruhi persepsi reputasi dan persepsi jaminan struktural terhadap niat menggunakan layanan keuangan berbasis online (internet-only bank).

\section{KESIMPULAN}

Berdasarkan hasil analisis, sikap calon investor khususnya generasi milenial dalm niat berinvestasi di platform P2P lending terbukti dapat dipengaruhi oleh faktor kepercayaan yang direalisasikan pada perwujudan suatu perilaku untuk mempersepsikan reputasi dan jaminan struktural platform P2P lending. Generasi milenial akan membentuk niat berinvestasi dalam upaya untuk melakukan suatu tindakan berdasarkan aspek-aspek persepsi yang dapat dinilai. Hal tersebut ditunjukkan bahwa terdapat pengaruh langsung yang signifikan antara persepsi reputasi, persepsi jaminan struktural, serta kepercayaan terhadap niat investasi di platform P2P lending. Selain itu, hasil pengujian pengaruh tidak langsung antara persepsi reputasi terhadap niat investasi melalui kepercayaan menunjukkan hasil yang signifikan. Hal yang sama juga ditemukan bahwa terdapat hasil yang signifikan dari pengaruh tidak langsung antara persepsi jaminan struktural terhadap niat investasi melalui kepercayaan.

Calon investor generasi milenial memiliki kepercayaan bahwa platform P2P lending mempunyai perlindungan hukum, teknologi keamanan, jaminan asuransi untuk memastikan keberhasilan transaksi serta dapat melindungi dana investasi. Selain itu, popularitas platform P2P lending juga dapat memengaruhi 
pandangan responden untuk menggunakan platform tersebut dalam berinvestasi. Namun, masih terdapat kecenderungan bahwa persepsi reputasi terhadap platform P2P lending dianggap kurang baik. Oleh sebab itu, kepercayaan konsumen berperan penting untuk dapat meningkatkan persepsi terhadap reputasi serta jaminan struktural dalam melakukan investasi di platform P2P lending sebagai media alternatif investasi baru.

\section{SARAN TEORITIS}

Secara empiris penelitian dalam model niat konsumen untuk berinvestasi berbasis kepercayaan memberikan pandangan dari proses niat investasi menggunakan platform P2P lending. Selain itu, penelitian ini menggabungkan anteseden kepercayaan yang berkaitan dengan sifat investasi di P2P lending. Namun, masih terdapat hal-hal yang dapat digali lebih lanjut, sehingga diharapkan dapat mempertimbangkan variabel lainnya yang secara simultan dan komprehensif dapat berpengaruh pada niat investasi di platform P2P lending melalui kepercayaan. Variabel-variabel dalam aspek kepercayaan yang dapat dikaji lebih lanjut diantaranya kualitas informasi yang didasarkan pada cognition-based (Zhang et al., 2014), familiaritas yang didasarkan pada experienced-based (Afshan \& Sharif, 2016), serta electronic word-of-mouth (Falahat et al., 2019). Selanjutnya, penelitian ini memiliki beberapa keterbatasan karena meneliti platform P2P lending dalam investasi bentuk pinjaman secara umum, sementara investasi bentuk pinjaman terbagi menjadi dua kategori yaitu produktif dan konsumtif. Oleh karena itu, penelitian selanjutnya dapat terfokus pada satu kategori sehingga dapat melakukan uji beda atau perbandingan antara platform P2P lending yang menyajikan investasi bentuk pinjaman dengan kategori yang sama.

\section{SARAN PRAKTIS}

Hasil penelitian ini diharapkan dapat memberikan masukan serta pandangan kepada pelaku industri atau penyelenggara P2P lending untuk meningkatkan kepercayaan konsumen khususnya generasi milenial berinvestasi di platform P2P lending. Hal tersebut diperlukan karena hasil menunjukkan bahwa persepsi reputasi dan persepsi jaminan struktural merupakan prediktor yang kuat dari kepercayaan, sehingga penyelenggara diharapkan dapat memberikan perhatian khusus pada faktor-faktor tersebut untuk meningkatkan niat investasi khususnya generasi milenial di platform P2P lending. Selanjutnya, dalam hal jaminan struktural sangat penting bagi penyelenggara untuk dapat memastikan keamanan dana serta perlindungan transaksi yang secara signifikan dapat meningkatkan kepercayaan berinvestasi di platform $\mathrm{P} 2 \mathrm{P}$ lending. Oleh sebab itu, penyelenggara diharapkan dapat melakukan pengembangan teknologi yang dapat diandalkan pada fitur-fitur keamanan secara berkala untuk memastikan keamanan data, keamanan dana, serta keamanan bertransaksi dalam upaya menghindari akses yang tidak sah. Selain itu, penyelenggara platform $\mathrm{P} 2 \mathrm{P}$ lending perlu lebih meyakinkan calon investor generasi milenial untuk meningkatkan kesadaran yang didasarkan pada reputasi platform. Hal tersebut dapat diupayakan dengan cara membentuk komunitas online khusus investor yang dikelola dan digunakan secara baik untuk berbagi pengalaman serta komentar terhadap platform P2P lending, sehingga calon investor generasi milenial dapat menilai bentuk komunikasi antara penyelenggara dengan investor yang diharapkan dapat meningkatkan kepercayaan mereka untuk berinvestasi di platform $\mathrm{P} 2 \mathrm{P}$ lending.

\section{REFERENSI}

Afshan, S., \& Sharif, A. (2016). Acceptance of mobile banking framework in Pakistan. Telematics and Informatics, 33(2), 370-387. https://doi.org/10.1016/j.tele.2015.09.005

Ahmed, I. S. Y., \& Ali, Y. S. A. (2017). Determinants of continuance intention to use mobile money transfer: An integrated model. Journal of Internet Banking and Commerce, 22(7), 1-24. Retrieved from http://www.icommercecentral.com

Ajzen, I. (2005). Attitude, Personality, and Behavior. https://doi.org/10.1080/10410236.2018.1493416

Akroush, M. N., \& Al-Debei, M. M. (2015). An integrated model of factors affecting consumer attitudes towards online shopping. Business Process Management Journal, 21(6), 1-26. https://doi.org/10.1108/BPMJ-03-2016-0056

Bojang, I. (2017). Determinants of trust in B2C e-commerce and their relationship with consumer online trust. Journal of Internet Banking and Commerce, 22(8), 1-59. https://doi.org/10.1063/1.5013938 
[BPS] Badan Pusat Statistik. (2020). Potret Sensus Penduduk 2020 Menuju Satu Data Kependudukan Indonesia [online] https://www.bps.go.id/publication/download.html (accessed 5 january 2021).

Brodmann, J., Rayfield, B., Hassan, M. K., \& Thu Mai, A. (2018). Banking characteristics of millennials. Journal of Economic Cooperation and Development, 39(4), 43-73.

Chen, D., \& Han, C. (2012). A comparative study online P2P lending in The USA and China. Journal of Internet Banking and Commerce, 17(2), 1-15.

Cnbcindonesia.com. (2019). Fintech salahgunakan data konsumen, siap-siap kena denda [online] https://www.cnbcindonesia.com/tech/20190705141712-37-82978/fintech-salahgunakan-datakonsumen-siap-siap-kena-denda (accessed 5 january 2021).

DailySocial.id. (2019). Survei dailysocial dan populix: investasi reksa dana terpopuler di Indonesia [online] https://dailysocial.id/post/survei-dailysocial-populix-investasi-reksa-dana-terpopuler-indonesia-2020 (accessed 5 january 2021).

Deborah, W., \& Keni. (2019). Pengaruh persepsi kemudahan berbelanja, reputasi website, dan kualitas website terhadap minat beli online: kepercayaan sebagai variabel mediasi. Jurnal Manajemen Bisnis Dan Kewirausahaan, 3(1), 102-108. https://doi.org/10.24912/jmbk.v3i1.4933

Fahmi, S. (2018). Pengaruh persepsi keamanan dan kepercayaan terhadap niat konsumen dalam melakukan transaksi e-commerce, melalui sikap sebagai variabel intervening. JAMIN: Jurnal Aplikasi Manajemen Dan Inovasi Bisnis, 1(1), 86-96. https://doi.org/10.47201/jamin.v1i1.21

Falahat, M., Lee, Y. Y., Foo, Y. C., \& Chia, C. E. (2019). A model for consumer trust in E-commerce. Asian Academy of Management Journal, 24(2), 93-109. https://doi.org/10.21315/aamj2019.24.s2.7

Fu, H., Li, Y., \& Duan, Y. (2014). Does employee perceived reputation contribute to citizenship behavior? International Journal of Contemporary Hospitality Management, 26(4), 593-609.

Gunarso, L., Andriano, J., \& Sihombing, S. O. (2020). Keterhubungan antara kemampuan, kebajikan (benevolence), dan integritas perusahaan terhadap kepercayaan dan partisipasi pelanggan: studi empiris pada Tokopedia. Jurnal Muara Ilmu Ekonomi Dan Bisnis, 4(2), 330-342. https://doi.org/10.24912/jmieb.v4i2.8402

Hair, J. F., Black, W. C., Babin, B. J., \& Anderson, R. E. (2006). Multivariate Data Analysis (7th ed.). United Kingdom: Cengange Learning.

Herwin, \& Abadi, F. (2018). Pengaruh reputasi perusahaan dan reputasi vendor terhadap keputusan pembelian secara online dengan kepercayaan konsumen sebagai variabel antara. Jurnal Riset Manajemen Dan Bisnis, 3(3), 353-364.

Howe, N. \& Strauss, W. (2000). Millennials Rising: The Next Great Generation. $3^{\text {rd }}$ edition. Vintage Publisher.

Hsiao, K. L., Lin, J. C. C., Wang, X. Y., Lu, H. P., \& Yu, H. (2010). Antecedents and consequences of trust in online product recommendations an empirical study in social shopping. Online Information Review, 34(6), 935-953. https://doi.org/10.1108/14684521011099414

Jakpat. (2018). Indonesian millennials investment trend 2018 - survey report [online] https://jakpat.net/indonesian-millennials-investment-trend-2018-survey-report/ (accessed 5 january 2021)

Jang, S. H., \& Lee, C. W. (2018). The impact of location-based service factors on usage intentions for technology acceptance: The moderating effect of innovativeness. Sustainability, 10(6), 1-18. https://doi.org/10.3390/su10061876

Kaabachi, S., Ben Mrad, S., \& Petrescu, M. (2017). Consumer initial trust toward internet-only banks in France. International Journal of Bank Marketing, 35(6), 903-924. https://doi.org/10.1108/IJBM-092016-0140

Kim, D. J., Ferrin, D. L., \& Rao, H. R. (2008). A trust-based consumer decision-making model in electronic commerce: The role of trust, perceived risk, and their antecedents. Decision Support Systems, 44(2), 544-564. https://doi.org/10.1016/j.dss.2007.07.001

Kim, J. B. (2012). An empirical study on consumer first purchase intention in online shopping: Integrating initial trust and TAM. Electronic Commerce Research, 12(2), 125-150. https://doi.org/10.1007/s10660-012-9089-5 
Kim, J. U., Kim, W. J., \& Park, S. C. (2010). Consumer perceptions on web advertisements and motivation factors to purchase in the online shopping. Computers in Human Behavior, 26(5), 1208-1222. https://doi.org/10.1016/j.chb.2010.03.032

Kircova, I., \& Esen, E. (2018). The effect of corporate reputation on consumer behaviour and purchase intention. Management Research and Practice, 10(4), 21-32.

Koksal, M. H. (2016). The intentions of Lebanese consumers to adopt mobile banking. International Journal of Bank Marketing, 34(3), 327-346. https://doi.org/10.1108/IJBM-03-2015-0025

Kominfo.go.id. (2021). Satgas waspada investasi temukan 133 fintech P2P lending ilegal [online] https://www.kominfo.go.id/content/detail/32417/satgas-waspada-investasi-temukan-133-fintechp2p-lending-ilegal/0/berita (accessed 5 january 2021).

Maduku, D. K. (2016). The effect of institutional trust on internet banking acceptance: perspectives of South African banking retail customers. South African Journal of Economic and Management Sciences, 19(4), 533-548.

Maruping, L. M., Bala, H., Venkatesh, V., \& Brown, S. (2016). Going beyond intention: integrating behavioral expectation into the unified theory of acceptance and use of technology. Journal of the American Society for Information Science and Technology, 64(July), 1852-1863. Retrieved from http://onlinelibrary.wiley.com/doi/10.1002/asi.22883/abstract

Masrek, M. N., Halim, M. S. A., Khan, A., \& Ramli, I. (2018). The impact of perceived credibility and perceived quality on trust and satisfaction in mobile banking context. Asian Economic and Financial Review, 8(7), 1013-1025. https://doi.org/10.18488/journal.aefr.2018.87.1013.1025

Maziriri, E. T., Mapuranga, M., \& Madinga, N. W. (2019). Navigating selected perceived risk elements on investor trust and intention to invest in online trading platforms. Journal of Economic and Financial Sciences, 12(1), 1-14. https://doi.org/10.4102/jef.v12i1.434

McCole, P., Ramsey, E., Kincaid, A., Fang, Y., \& LI, H. (2019). The role of structural assurance on previous satisfaction, trust and continuance intention: The case of online betting. Information Technology and People, 32(4), 781-801. https://doi.org/10.1108/ITP-08-2017-0274

McKnight, D. H., \& Chervany, N. L. (2001). What trust means in e-commerce customer relationships: An interdisciplinary conceptual typology. International Journal of Electronic Commerce, 6(2), 35-59. https://doi.org/10.1080/10864415.2001.11044235

McKnight, D. H., Choudhury, V., \& Kacmar, C. (2002). The impact of initial consumer trust on intentions to transact with a web site: A trust building model. Journal of Strategic Information Systems, 11(34), 297-323. https://doi.org/10.1016/S0963-8687(02)00020-3

Mohy-Ul-Din, S., Samad, S., Rehman, M. A., Ali, M. Z., \& Ahmad, U. (2019). The mediating effect of service provider expertise on the relationship between institutional trust, dispositional trust and trust in takaful services: An empirical investigation from Pakistan. International Journal of Islamic and Middle Eastern Finance and Management, 12(4), 509-522. https://doi.org/10.1108/IMEFM-022018-0072

Ofori, K. S., Boateng, H., Okoe, A. F., \& Gvozdanovic, I. (2017). Examining customers' continuance intentions towards internet banking usage. Marketing Intelligence and Planning, 35(6), 756-773. https://doi.org/10.1108/MIP-11-2016-0214

Otoritas Jasa Keuangan. (2016). Peraturan Otoritas Jasa Keuangan Nomor 77/POJK.01/2016 Tentang Layanan Pinjam Meminjam Uang Berbasis Teknologi Informasi [online] https://www.ojk.go.id/id/regulasi/otoritas-jasa-keuangan/peraturan-ojk/Documents/Pages/POJKNomor-77-POJK.01-2016/SAL\%20-\%20POJK\%20Fintech.pdf (accessed 5 january 2021).

Rahi, S., Yasin, N. M., \& Alnaser, F. M. (2017). Measuring the role of website design, assurance, customer service and brand image towards customer loyalty and intention to adopt internet banking. Journal of Internet Banking and Commerce, 21(8), 1-18.

Saputro, Laturette A. A., \& Kazia. (2018). Pengaruh literasi keuangan terhadap perilaku konsumtif generasi milenial dengan latar belakang akuntansi. Prosiding - Konferensi Regional Akuntansi (KRA) V Malang. 
Septyanto, D. (2013). Faktor-kaktor yang mempengaruhi investor individu dalam pengambilan keputusan Investasi Sekuritas di Bursa Efek Indonesia (BEI). Jurnal Ekonomi, 4(2), 90-101.

Shahnaz, N. B. F., \& Wahyono. (2016). Faktor-faktor yang mempengaruhi minat beli konsumen di toko online. Management Analysis Journal, 389-399. https://doi.org/10.1103/PhysRevSeriesI.32.254

Shao, Z., Zhang, L., Li, X., \& Guo, Y. (2018). Antecedents of trust and continuance intention in mobile payment platforms: The moderating effect of gender. Electronic Commerce Research and Applications. https://doi.org/10.1016/j.elerap.2018.100823

Smith, T. J. \& Nichols, T. (2015). Understanding the millennial generation. The Journal of Business Diversity, 15(1), 39-47.

Stern, C., Makinen, M., \& Qian, Z. (2017). FinTechs in China with a special focus on peer to peer lending. Journal of Chinese Economic and Foreign Trade Studies, 10(3), 215-228. https://doi.org/10.1108/JCEFTS-06-2017-0015

Sugiharto \& Sitinjak, T. (2004). Strategi Menaklukan Pasar Melalui Riset Ekuitas dan Perilaku Merek. Gramedia Pustaka Utama.

Tangmanee, C., \& Rawsena, C. (2016). Direct and indirect effects of perceived risk and website reputation on purchase intention: A mediating role of online trust. International Journal of Research in Business and Social Science, 5(6), 1-11.

Van Deventer, M., De Klerk, N., \& Bevan-Dye, A. (2017). Antecedents of attitudes towards and usage behavior of mobile banking amongst Generation Y students. Banks and Bank Systems, 12(2), 78-90. https://doi.org/10.21511/bbs.12(2).2017.08

Wang, M., Wang, T., Kang, M., \& Sun, S. (2014). Understanding perceived platform trust and institutional risk in peer-to-peer lending platforms from cognition-based and affect-based perspectives. Proceedings - Pacific Asia Conference on Information Systems, PACIS 2014.

Wang, S. W., Ngamsiriudom, W., \& Hsieh, C. H. (2015). Trust disposition, trust antecedents, trust, and behavioral intention. Service Industries Journal, 35(10), 555-572. https://doi.org/10.1080/02642069.2015.1047827

Wang, Z., Guan, Z., Hou, F., Li, B., \& Zhou, W. (2019). What determines customers' continuance intention of FinTech? Evidence from YuEbao. Industrial Management and Data Systems, 119(8), 1625-1637. https://doi.org/10.1108/IMDS-01-2019-0011

Wingreen, S. C., Mazey, N. C. H. L., Baglione, S. L., \& Storholm, G. R. (2019). Transfer of electronic commerce trust between physical and virtual environments: experimental effects of structural assurance and situational normality. Electronic Commerce Research, 19(2), 339-371. https://doi.org/10.1007/s10660-018-9305-z

Yahia, I. Ben, Al-Neama, N., \& Kerbache, L. (2018). Investigating the drivers for social commerce in social media platforms: Importance of trust, social support and the platform perceived usage. Journal of Retailing and Consumer Services, 41, 11-19. https://doi.org/10.1016/j.jretconser.2017.10.021

Yan, Y., Lv, Z., \& Hu, B. (2018). Building investor trust in the P2P lending platform with a focus on Chinese P2P lending platforms. Electronic Commerce Research, 18(2), 203-224. https://doi.org/10.1007/s10660-017-9255-X

Yang, M., Li, H., Shao, Z., \& Shang, W. (2017). Influencing Lenders' Repeat Investment Intention in P2P Lending Platforms in China through Signaling. Pacific Asia Conference on Information Systems Proceedings.

Zhang, T., Tang, M., Lu, Y., \& Dong, D. (2014). Trust building in online peer-to-peer lending. Journal of Global Information Technology Management, 17(4), 250-266. https://doi.org/10.1080/1097198X.2014.978624 